\title{
Historical Origins of Environment Sustainability in the German Chemical Industry, 1950s-1980s
}

\section{Citation}

Jones, Geoffrey, and Christina Lubinski. "Historical Origins of Environmental Sustainability in the German Chemical Industry, 1950s-1980s." Harvard Business School Working Paper, No. 14-018, August 2013.

\section{Permanent link}

http://nrs.harvard.edu/urn-3:HUL.InstRepos:11508212

\section{Terms of Use}

This article was downloaded from Harvard University's DASH repository, and is made available under the terms and conditions applicable to Open Access Policy Articles, as set forth at http:// nrs.harvard.edu/urn-3:HUL.InstRepos:dash.current.terms-of-use\#OAP

\section{Share Your Story}

The Harvard community has made this article openly available.

Please share how this access benefits you. Submit a story.

Accessibility 
H A R VAR D

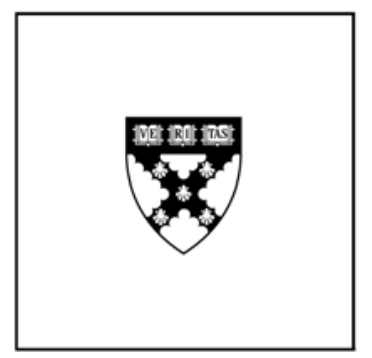

\section{Historical Origins of Environment Sustainability in the German Chemical Industry, 1950s-1980s}

Geoffrey Jones

Christina Lubinski

\section{Working Paper}

14-018

August 30, 2013 
Historical Origins of Environment Sustainability in the German Chemical Industry,

1950s-1980s

Geoffrey Jones

Christina Lubinski 


\section{Historical Origins of Environment Sustainability in the German Chemical Industry, 1950s-1980s}

Abstract

This working paper examines the growth of corporate environmentalism in the West German chemical industry between the 1950s and the 1980s. It focuses on two companies, Bayer and Henkel and traces the evolution of their environmental strategies in response to growing evidence of pollution and resulting political pressures. Although German business has been regarded as pioneering corporate environmentalism, this study reveals major commonalities between the German and American chemical industries until the 1970s, when the two German firms diverged from their American counterparts in using public relations strategies not only to contain fallout from criticism, but also as opportunities for changes in corporate culture. The working paper finds no evidence for variety of capitalism explanations why German firms should have been early in their sustainability strategies, partly because of the importance of regional as opposed to national influences, but the study is supportive of organizational sociology theories which have identified the importance of visibility in corporate green strategies.

Keywords: environmental strategies, corporate responsibility, sustainability, chemical industry, detergents, Germany 


\section{The Origins of Environment Sustainability in the German Chemical Industry, 1950s-}

$1980 \mathrm{~s}^{1}$

This working paper explores the evolution of environmental strategies in the German chemical industry between the 1950s and the 1980s. Historical research on corporate environmental policies remains skewed. A vibrant environmental history literature has often identified business as a primary agent in environmental degradation, but it has usually not delved deeper into corporate strategies. The business history literature has only recently engaged with the topic of business and the environment, ${ }^{2}$ And the history of corporate responsibility more generally. ${ }^{3}$ This may reflect a disciplinary bias towards exploring issues related to innovation and growth, or else the failure to achieve them, rather than addressing negative outcomes of such innovation and growth.

It is well-established that the emergence of concerns that industrialization and modernization were damaging the natural environment date back to the nineteenth century. ${ }^{4}$ These concerns were driven by early ecologists, philosophers and scientists rather than business leaders, although by the late nineteenth century industrial pollution in major US cities such as Chicago and St. Louis was so evident that it encouraged a handful of business leaders to organize to persuade the business community to voluntarily seek ways to control such pollution. ${ }^{5}$ During the era of German industrialization in the late nineteenth and early twentieth century, conservationists also lamented the dangerous impact of chemical effluents on water and air. ${ }^{6}$ However after 1914 the era of world wars, virulent nationalism, and economic crisis did not provide a favourable context for the continued growth of environmental consciousness. ${ }^{7}$ Environmentalism became, if anything, associated with rightwing political extremism. Historians were distressed the discover that the Nazi regime introduced pioneering environmental legislation in Germany during the 1930s, although given 
the other policies of the criminal regime claims that the Nazi's were "proto-Greens" are clearly wholly misplaced.

After the end of World War 2, attention was more focused on economic recovery, but the renewal of a more widely based environmental movement was propelled by a growing number of accidents and pollution incidents. There was a new articulation of environmental threats. Rachel Carson's Silent Spring had a much-observed impact in raising awareness of the detrimental environmental impact of pesticides. ${ }^{8}$ In 1972 the United Nations held the first Conference on the Human Environment in Stockholm, which was followed by a new environmental legislation in Europe. ${ }^{9}$

Rising environmental concerns, and the legislation which it stimulated, had substantial consequences for businesses, and especially for those who were directly associated with activities deemed polluting. In post-war France, Boullet has described the emergence of environmental strategies in heavy industries, including chemicals, in response to regulation, ecological disasters and shifting public opinion. ${ }^{10}$ The literature on the United States is larger. Hoffman, in a study of the chemical and petroleum industries, identified an evolution of corporate strategies over time. During the 1960s many US corporations believed that environmental concerns were exaggerated, and if there were problems, that they could handle them. In the wake of the 1970 Environmental Protection Act, there was a somewhat sullen commitment to technical compliance with the law. During the 1980s, as environmental activism rose, US firms began to engage more proactively in establishing environmental rules. $^{11}$

Hoffman's study forms part of a wider literature on the history of environmental management and strategy in the post-war chemical industry, including studies by Colten and Skinner, Markowitz and Rosner, and Ross and Amter. ${ }^{12}$ For the most part, these studies are critical of the industry's claims to be following best practices during the post-war decades, 
and frequently criticise a gap between the public statements of firms and what they actually knew about pollution. On a similar line, there are studies by Kehoe and by McGucken, concerning the pollution caused by the discharge of detergents into lakes and rivers, although these authors also note the scientific uncertainties faced by policy makers and companies. ${ }^{13}$ These studies have limited firm-level analysis. One exception is Smith's survey of the environmental policies of DuPont, which is more positive about the company's environmental strategies, and also stresses the uncertain toxicological knowledge on which decisions needed to be made. ${ }^{14}$ In other industries and countries, firm-level studies have also pointed towards imperfect information as a constraint, as well as organizational deficiencies within the firms themselves. $^{15}$

This working paper takes a firm and industry level perspectives, and focuses on postwar Germany. The choice of country is deliberate. The German Federal Republic (hereafter West Germany) as a country has often been considered as a European pioneer in green policies. In 1979 the Green political party was founded in West Germany, and became the first European Green party to make a major political impact in 1983, when it won 28 seats in the Bundestag (the West German parliament). ${ }^{16}$

German business has also been seen as a pioneer in addressing environmental issues. A 1995 study asserted that German business had been a top spender "for a cleaner environment... since the early 1970s." ${ }^{17}$ However it is not clear how this happened, or whether it is really true, as there has been less historical research on green business strategies in West Germany compared to the United States. Most research has focused on the issue of industrial pollution primarily before 1945 , and is heavily focussed on government policy. ${ }^{18}$ While business has been identified as a major polluter, firm strategies have not been discussed in detail in recent studies of the evolution of environmental policy, including Uekötter's 
comparative study of German and American policies on air pollution before 1970. Uekötter mentions Bayer only once and Henkel not at all. ${ }^{19}$

The theory of why some firms become "greener" than others is still being developed. The international political economy literature has sought explanations in the varieties of capitalism model. Mikler, in a comparative study of the automobile industry, has argued that firms in coordinated market economies, such as Germany and Japan, are more inclined to adopt greener strategies than their counterparts in liberal market economies, such as the United States and Britain. It has been suggested that firms in such coordinated market economies operated with a framework of collaborative-consensus setting between business and government, that companies incorporated consumer attitudes rather than price signals in their strategies, and that soft topics counted more in internal corporate strategy. ${ }^{20}$

In the organizational sociology literature, there is also an emergent body of theory seeking to understand why some firms selectively disclose information about their environmental impacts, more colloquially known as greenwashing. This literature builds on earlier work which has explored how an organization's visibility affects compliance with institutional pressures. There is evidence that greater visibility makes organizations more concerned with their legitimacy, although other research has suggested that the more powerful an organization the more it can afford to resist pressures from external stakeholders. ${ }^{21}$ Marquis and Toffel have employed a large-scale comparative sample on corporate environmental disclosure to distinguish between "generic visibility," such as just being big and well-known, and "domain-specific visibility," such as being identified specifically with an issue like worker safety, which exposes it to special scrutiny and is more likely to prompt more transparent disclosure. ${ }^{22}$

This working paper will examine the strategies of two prominent chemical companies, Bayer and Henkel to establish how far the assumption that post-war German business was 
greener than others, is supported. This question is comparative, and comparisons will be made with, especially, the better-researched American case. Bayer and Henkel are not "representative" of the German chemical industry in a formal sense, but they do provide valuable cases to test hypotheses. Both companies have been described, and have selfidentified, as "eco-pioneers." ${ }^{23}$ They differ in size, product markets and ownership structure, but share a common regional base. Both companies have also provided access to their corporate archives, enabling a more nuanced understanding of corporate motivations and internal organizational issues. After having found supporting evidence that these German firms might have comparatively early in their environmental policies, the article will test how far the variety of capitalism and organizational sociology hypotheses discussed above are helpful as explanatory variables.

Section 2 provides a brief history of Bayer and Henkel, identifying the similarities and differences between them. Section 3 discusses the mounting public criticism of their environmental impact during the post-war decades. Section 4 analyses the corporate response to pollution criticisms before 1969. Section 5 examines corporate strategies during the 1970 s, when a real divergence appears to happen between the German and US firms.

\section{Bayer and Henkel - History and Governance}

Bayer and Henkel shared many similarities as long-established members of the top-tier of the German chemical industry. They were founded in 1863 and 1876 respectively. Both were located in the state of North Rhine-Westphalia (NRW) near the river Rhine. Henkel was headquartered in Holthausen, in the south of Düsseldorf, after 1878, while Bayer settled in Leverkusen in 1900, where it made its head office twelve years later. Both companies became closely associated with their home regions. ${ }^{24}$ At the turn of the twentieth century Bayer was one of the top three chemical companies in the successful German chemical industry, and 
Henkel was the fourth largest. In 2013 Bayer and Henkel were also the second and fourth largest chemical companies in Germany. ${ }^{25}$

Yet the companies were not identical twins. While Henkel largely made consumer products, especially cleaning products, Bayer earned many of its profits through producer sales. While both companies were confronted with the environmental impact of their products and processes, Henkel's premier position in detergents exposed it to one of the most publicised issues of industrial pollution after 1945. Finally, while Bayer became a public company as early as 1881, Henkel remained a family firm. In 1975, Henkel changed its legal form to a $\mathrm{KGaA}$, a distinctive German corporate form which was a hybrid between a partnership and a public corporation, and ten years later the company issued preference shares to the public, with no voting rights. ${ }^{26}$

The growth of both companies mirrored the history of modern Germany. Henkel was founded in 1876 by Fritz Henkel and two partners. Henkel's first product was a universal detergent based on silicate. In contrast to similar products that at that time were sold loose, one of Henkel's main innovations was to sell the heavy-duty detergent in handy packets. In 1878, the company launched its first branded detergent, the Henkel's Bleich-Soda (Bleaching Soda). In 1907, Henkel introduced the laundry detergent Persil, a self-acting detergent which made rubbing and bleaching unnecessary. ${ }^{27}$ After 1933, although individual members of the Henkel family were critical of the regime, most of the firm's top managers joined the Nazi party and cooperated with the authorities, including using slave labour. After the end of World War 2, five members of the family and another seven members of the Management Board and the Supervisory Board were interned by the Allies. They were rehabilitated in November $1947 .^{28}$

Bayer was founded by dye salesman, Friedrich Bayer (1825-1880), and master dyer Johann Friedrich Weskott (1821-1876) in 1863. The company made synthetic dyestuffs, 
whose production from coal-tar derivatives had only been invented a few years previously. Dyestuffs were sold primarily to the textile industry, which was growing rapidly during German industrialization. Bayer also diversified, especially into pharmaceuticals. In 1899, it developed and launched Aspirin, its most famous branded pharmaceutical product. ${ }^{29}$ By 1914 the company had many international subsidiaries, which were all lost as a result of the War. In 1925 Bayer and the other German dye companies merged to form I.G. Farbenindustrie AG. During the Nazi era I.G. manufactured synthetic rubber and fuel, and infamously was the supplier for the gas chambers in concentration camps. ${ }^{30}$ In 1945, the Allies confiscated I.G., and put two dozen of its managers on trial. ${ }^{31}$ I.G. was broken up in 12 individual companies, one of these being Bayer.

After 1945 German big business, including Bayer and Henkel, sought to rebuild reputations, promoting themselves as pillars of a "social market economy" which was conceived as an economically successful, but more humane, alternative to American-style capitalism. ${ }^{32}$ Family-owned and managed companies such as Henkel were highlighted as exemplars of this German-style capitalism. ${ }^{33}$ In fact, an emphasis on the broader societal responsibilities of business was also prevalent in the United States and elsewhere. Spector has traced the roots of the modern Corporate Social Responsibility movement back to the Dean of the Harvard Business School, Donald K. David, during the late 1940 and 1950s. ${ }^{34}$

As major chemical manufacturers, Henkel and Bayer were important participants in West Germany's post-war "economic miracle." This made the chemical industry, in the language of sociology, highly visible. Table 1 provides data on the growth of the revenues, profits and employment of the two firms between 1950 and 1980. 
Table 1: Revenues, Profits and Employment at Bayer and Henkel, 1950-1980

\begin{tabular}{|c|c|c|c|c|c|}
\hline & 1950 & 1960 & 1970 & 1980 & $1950-1980(\%)$ \\
\hline \multicolumn{6}{|l|}{ Bayer } \\
\hline Revenue (million D-Mark) & 599 & 2,818 & 9,524 & 28,825 & \\
\hline CAGR (\%) & & 16.7 & 12.9 & 11.7 & 13.64 \\
\hline Profits (million D-Mark) & $\begin{array}{c}16 \\
(1952)\end{array}$ & 132 & 358 & 730 & \\
\hline CAGR (\%) & & 23.49 & 10.49 & 7.39 & 13.44 \\
\hline Number of employees & 30,009 & 58,500 & 110,200 & 181,639 & \\
\hline CAGR $(\%)$ & & 6.90 & 6.54 & 5.12 & 6.12 \\
\hline \multicolumn{6}{|l|}{ Henkel } \\
\hline Revenue (million D-Mark) & 248 & 677 & 1,820 & 6,899 & \\
\hline CAGR (\%) & & 10.5 & 10.4 & 14.25 & 11.60 \\
\hline Profits (million D-Mark) & 8 & $\mathrm{n} / \mathrm{a}$ & $54(1974)$ & 86 & \\
\hline$C A G R(\%)$ & & & & 4.76 & \\
\hline Number of employees & 4,961 & 9,362 & 14,217 & 12,736 & \\
\hline$C A G R(\%)$ & & 6.56 & 4.27 & $(1.09)$ & 3.19 \\
\hline
\end{tabular}

Sources: Bayer - BA Geschäftsberichte, 1951-1991; Henkel - Feldenkirchen, Menschen, 145 and 186.

This fast growth initially reflected recovery from the wartime nadir rather than profitability. Cassis's comparative study of the profitability of large German, British and French firms shows Bayer earning only a motley $4 \%$ return on shareholder funds between 1953 and 1955. Like all the German companies, it was far behind its American counterparts in 
commercializing products from petrochemicals. However even Britain's largest chemical company, ICI, only earned a $6.7 \%$ return. It is not possible to make a direct comparison with Henkel as the family firm did not disclose profits, but it is known that it badly lagged its American competitors, led by Procter \& Gamble (hereafter P \& G), in the new technology of synthetic detergents. ${ }^{35}$ Both Bayer and Henkel invested heavily to rebuild their competitiveness. The former gained entry into petrochemicals using joint ventures, and invested further in pharmaceuticals. Henkel fought off the entry of P \& G into Germany during the 1960s, and by 1968 had almost 50 per cent of the European detergent market. ${ }^{36}$ Between 1970 and 1972 Cassis shows Bayer's return to shareholders as 9.5\% and Henkel's at 9.7\%, compared to ICI's 9.5\%. By this measure the two German companies were in Cassis's ranking of the eight most profitable German companies at that time, although they were significantly less profitable than the automobile companies Daimler-Benz (17.2\%) and BMW $(14.1 \%) .{ }^{37}$ The oil price rises of 1973 were a more difficult time for chemical companies as indicated by Bayer's slowing revenue and profit growth, and Henkel's falling employment, shown in table 1.

\section{The Rise of Pollution as a Political Issue}

In the wake of the devastation caused by World War 2, environmental issues were not at the forefront of either political or corporate agendas. Unlike in many American cities, where debates about air and water pollution were underway, German society was struggling with economic reconstruction, the rebuilding of bombed cities, the integration of millions of displaced people, and the ethical collapse of Nazism. The chemical industry was hailed as a pillar of reconstruction, and a champion of Germany's burgeoning export economy. Pollution was accepted as a necessary evil. ${ }^{38}$ However, as the economy recovered, environmental problems, especially air and water pollution, emerged in public discourses. ${ }^{39}$ 
Pollution was especially evident in the industrialized region of NRW. A report by independent experts in 1961 showed that there was heavy air and water pollution near the Henkel and Bayer factories. ${ }^{40}$ Local residents complained about unpleasant black smoke, carbon black particles, and bad odours. Residents living near the main Henkel factory wrote to the company complaining about increases in carbon black output, gas smells, and soot. ${ }^{41}$ During 1962 one resident repeatedly drove his car to the Henkel headquarters showing the black and white particles dirtying his Mercedes. ${ }^{42}$

Residents near the Bayer factory at Leverkusen also complained. In 1958 Bayer had installed a giant illuminated version of its logo, the Bayer Cross, overlooking Leverkusen. It was the largest illuminated advertisement in the world, and might be considered a symbol of "domain-specific visibility." The problem was that it shone over a stinking city. Bayer received growing complaints about foul air, and especially the acidic effluents which stank, destroyed garden plants, caused headaches, and ruined women's nylons. Bayer paid compensation for the nylons, but officially maintained that they must have been of poor quality to be affected by the effluents. ${ }^{43}$ In one official report initiated by the city of Düsseldorf covering the years 1958 to 1961 , Bayer was directly accused of emitting too much ash and sulphur dioxides into the air, and requested to build taller chimneys with the idea that pushing the air high up in the atmosphere would help to thin out the pollution. ${ }^{44}$

The NRW was no stranger to bad smells. The traditional corporate response to complaints was to stress the importance of the industry. During the early 1950s Henkel's managers regularly stated that odour nuisances could not be further reduced, and that the neighbours would just have to live with them. ${ }^{45}$ A decade later Bayer's managers were still asserting in public that the discharged air was not harmful to humans, and that any nuisances should be accepted for the sake of employment and economic development. ${ }^{46}$ The pollution just got worse. In the mid-1960s, a phenomena known as "Auto-Pocken" ("car-pox") 
appeared near Bayer's factories. Effluents caused severe paint damage on 7,000 cars. Bayer paid almost one million D-Mark in compensation (approximately $£ 89,600$ ). ${ }^{47}$ The mysterious damage, whose cause could not be determined with certainty, had a distinctly negative impact on Bayer's image in the neighbourhoods affected. ${ }^{48}$

Factory effluents in water were also a source of major concern. Between 1949 and 1952 local authorities repeatedly warned Henkel not to release allegedly dangerous effluents into the public wastewater system. Bayer also faced an alarming number of dead fish close to its factory on the Rhine, which was attributed to a high level of Phenol released by Bayer. ${ }^{49}$

Water impureness became even more obvious in the hot and dry summer of 1959 , when the water levels of rivers and lakes were exceptionally low. A significant amount of synthetic colours were detected in the Rhine. While it was not unusual to see a kaleidoscope of colours in the Rhine, the low water level made the effluents even more visible. The water police took samples and sent them to Bayer for further analysis. The long-standing relations between the local authorities and the firm was reflected in the fact that it was left to the company to determine the cause for pollution because, as Bayer managers stated, "they value our analytical competencies." ${ }^{50}$

However it was foam on the Rhine rather than dead fish which really raised public concerns in the NRW. The problem stemmed from the use of alkyl benzene sulphonate derived from cheap petrochemicals benzene and propylene, as the main cleaning agent in synthetic detergents. The surfactants did not bio-degrade, accumulated within treatment plants, and entered rivers and lakes. By the late 1950s, a highly visible foam was found in rivers and lakes across Europe and the United States. ${ }^{51}$ In Germany, as elsewhere, the detergents industry was soon identified as the culprit. In 1961, the popular national periodical Zeit, issued twice a month, ran a story with the title "The water is sick. What to do with the scum of civilization?" ${ }^{52}$ 
Foamy rivers and car-pox began to erode the high status held by the chemical industry as a pillar of West Germany's economic reconstruction. The industry was well-protected by the post-war legal and political system. The German legal system formally prioritized economic performance over the protection of victims of pollution. The Gewerbeordnung (Prussian Industrial Code) of 1869/1900, still in force, stipulated that companies needed a license for new factories, which could be denied if the plant could be expected to cause unbearable risks or nuisances for its neighbours, but for existing factories, the only legal recourse for residents affected by pollution was to engage in private law suits. There was no enthusiasm to disrupt the activities of national champions. In 1959, the Prussian Industrial Code was finally modified to strengthen the rights of residents living around factories to sue for financial compensation. ${ }^{53}$ However, it was difficult to prove cause, and local authorities left it to companies to determine the cause of pollution.

Critical voices struggled to get traction. In 1952 Sturm Kegel, the director of the Ruhr Area Federation for Regional Planning, presented a detailed plan to establish Luftreinhaltegenossenschaften (air pollution control cooperatives) in NRW, aimed at bringing together companies, local municipalities and regional planners to jointly implement measures against air pollution. Kegel's concept was heavily criticized by public officials and industry representatives and eventually rejected, but it did prompt a debate and helped to raise the profile of air pollution as a political issue in NRW. On the federal level, an SPD member of parliament prepared a proposal for air pollution management for deliberation in the Bundestag in 1955. The professional association Verein Deutscher Ingenieure (Association of German Engineers), or VDI, volunteered to draft technical guidelines to monitor air pollution. ${ }^{54}$

Legislators remained cautious to move beyond monitoring. In NRW, the issue of water management was transferred from the Ministry of Economics to the Ministry of Agriculture in 1953 to assure ecological concerns were well-represented. The state 
government at the time was controlled by the conservative CDU party, which governed NRW between 1950 and 1956 and again between 1958 and 1966, but the business newspaper Handelsblatt criticised the move on the grounds that in such a heavily industrialized region the management of a key resource such as water ought to be in the hands of the Ministry of Economics. ${ }^{55}$ There were no new restrictions on industry, but a 10 -year-plan to improve the water infrastructure and the building of treatment plants emerged. The NRW government made over 75 million D-Mark (£6.75 million) available. The Bundestag also passed a Water Resources Act in 1957, which went into effect in 1960, initiating the building of new water treatment plants and other improvements of the water infrastructure. In 1962 the NRW's Ministry of Agriculture stated that the measures had delivered few visible results, especially in the context of a growing population and rising industrial production. Waste water was still perceived to be a major a problem, and a further State Water Act was passed in 1962. ${ }^{56}$ Overall, these water management initiatives imposed few restrictions on industry, and were little more than devices to create structures for studying problems, much as was parallel legislation in the United States. ${ }^{57}$ The exception was the detergent industry. The rising public outcry about detergent foam on rivers and lakes led to a Detergents Act being passed in 1961 which legally mandated the use of at least 80 per cent biodegradable detergents from 1964 onwards. ${ }^{58}$

During the federal election campaign in 1961, the candidate of the left-wing, Social Democratic Party (SPD), Willy Brandt, put forward a bold demand in a speech at the party convention: "The sky above the Ruhr must become blue again." ${ }^{59}$ While this issue was not central to his speech, clean air was emerging as a topic which resonated with voters. Brandt lost the election, but the victorious CDU was alert to public discomfort, and its potential political fallout. The Federal Chancellor's office under Konrad Adenauer had already proposed inquiries into environmental matters in the summer of 1960, "with a view towards 
the coming elections. ${ }^{\prime 60}$ The influential weekly Spiegel echoed Brandt's phrase in a title story about air pollution in NRW titled "Toward blue skies." In eleven well-illustrated pages, the article described dirt-covered and dying plants, sick children, and automobile accidents due to the reduced visibility and roads made slippery by dust particles. ${ }^{61}$

There were no radical changes in either legislation or corporate policies after 1961. However, there was a new willingness on the part of the NRW regional authorities to push back when Bayer, Henkel and the other companies sought to acquire licenses for new factories. In their applications, the companies employed the concept of Gewerbefreiheit ("freedom of occupation") which included the freedom to practice any trade or craft and, closely connected to it, the freedom to take one's residence where one wished. Both Bayer and Henkel pleaded for their autonomy on these grounds when it came to locational decisions. ${ }^{62}$ Yet an increasingly concerned public informed by critical investigative journalists made their voices heard, and the willingness of local politicians to listen to them was discernible. ${ }^{63}$

\section{Corporate Policies towards Pollution in the 1950s and 1960s}

Henkel and Bayer managers were not born "eco-pioneers." During the post-war decades corporate policies towards the environment evolved slowly, grudgingly, and in response to mounting complaints.

In 1958 Henkel responded to criticisms by founding a Water Pollution Control Laboratory to monitor water pollution. It made incremental improvements to existing factories to curb effluent emissions, and helped design new factories with better water pollution controls. ${ }^{64}$ The more substantive investment came in detergents. In response to the foam issue, Henkel began working on a biodegradable alternative to the cleaning agents in synthetic detergent after 1953. It had a product ready by the time the 1961 Detergents Act was passed. ${ }^{65}$ This was not especially early in comparative terms. In the United States mounting 
threats of legislation led the major detergents manufacturers to invest in alternatives. P \& G made a substantial research investment, and in 1965 the American industry voluntarily switched to use a new, biodegradable alternative. Two years later the major detergents manufacturers in Europe also concluded a voluntary agreement to use biodegradable surfactants. ${ }^{66}$

Bayer also began to reform organizational structures to raise the profile of environmental issues. In 1954 Bayer turned its committees for clean water and clean air, which had been founded fifty-three years previously, into an Effluents and Waste Air Laboratory (ㅁffaelle, Wasser, $\underline{\text { Luft }}$, hereafter AWALU) designed to find solutions to deal with effluent pollution. The chemists and engineers working in the unit consulted with the different Bayer factories, and monitored and documented factory pollution. ${ }^{67}$ In 1964 , an independent Unit for Water Pollution Control and Emission Protection was established. By 1967, Bayer had also developed a plan for air pollution control, which utilized television cameras for monitoring visible effluents. Three young employees were put on bicycles to look for effluents on the ground, while a monitoring car checked for incidents just outside the Bayer plant. Effluents were also measured at the canals and the chimneys. ${ }^{68}$ As at Henkel, the pace of organizational change and policy implementation can only be considered modest.

Henkel and Bayer invested in waste cleaning facilities, but again at a leisurely pace. In 1957, Henkel completed its first central water purification system to process wastewater before releasing it into municipal sewage systems at the main Düsseldorf plant. ${ }^{69}$ Bayer also invested in air and water purification facilities. Of the 56 air cleaning facilities Bayer operated in 1956, 37 were built after $1950 .^{70}$ There was further investment during the 1960s. Bayer's investment in new plants and improvements to existing plants to enhance environmental protection rose from 23 million D-Mark ( $£ 2$ million) in 1963 to 91 million ( $£ 10.3$ million) in $1970 .^{71}$ 
It was managers at the front line of environmental issues at the local level who most understood the need for change. In 1960, the AWALU unit at Bayer reported to a top manager that complaints about polluted air and related damages in neighbouring residential areas had increased alarmingly, and argued that it would no longer suffice to argue that environmental pollution was unavoidable. ${ }^{72}$ Letters from local residents complaining about noise, smell, or smoke were received by Bayer and Henkel practically on a daily basis. At an internal meeting of Henkel's senior managers in 1960, the problem was discussed in detail because "it burdens (...) our relationship to our neighbours. ${ }^{173}$ It became standard procedure at both companies to respond to letters from local residents, sometimes with personal invitations to visit factories. However managers often struggled to make the case within their own organizations. The head of AWALU complained that the anti-pollution measures were not implemented effectively in factories due to resistance in the workplace. ${ }^{74}$ Henkel also felt a need to educate staff about environmental issues, employing the house journal to communicate information about pollution problems. The company also regularly diffused water pollution laws to factory managers. ${ }^{75}$ There was significant labour turnover at both firms, which made the challenge of educating staff on environmental issues a continuing one. ${ }^{76}$

Bayer and Henkel relied on industry and professional organizations as the first defence against critical press coverage. In the mid-1950s, the VDI, which was responsible for the setting of technical guidelines for air pollution control, set up a working group "on publication issues" with the aim of "countering the public's mistrust (...) through objective information, creating a sphere of trust between emitters and those affected." ${ }^{77}$ The German Chemical Industry Association, an industry organization which represented firms in contacts with politicians, public authorities, other industries, and the media, pursued a similar strategy of seeking to deflect criticism by showcasing the industry's efforts to deal with effluent problems. ${ }^{78}$ It also continued to assert that pollution problems were a necessary price to pay 
given the industry's regional and national importance. ${ }^{79}$ The same argument continued to be used by the firms in their public statements, with the added refinement that further state regulation would handicap them in global markets. ${ }^{80}$

The two firms, and the German Chemical Industry Association, leveraged their long history of consultation and cooperation with local and regional officials as well as the federal government to seek to influence the content of regulation. ${ }^{81}$ With regard to air pollution, Bayer explained to the local authorities in 1966 that nothing could be achieved without the cooperation and the goodwill of the industry. ${ }^{82}$ Regulations usually evolved slowly in cooperation with the industry. The VDI's guidelines for air pollution standards, for example, were initially merely nonbinding suggestions. Managers at Henkel and Bayer noted internally that the Federal government waited for such guidelines before setting legal standards for the industry. ${ }^{83}$

The interaction of firms, industry and professional associations, and policy-makers might appear to fit the varieties of capitalism description of post-war West Germany capitalism. ${ }^{84}$ In fact, there were strong commonalities between what happened in Germany and the United States during the 1950s and 1960s. The American chemical industry, like the German, asserted that it was essential for economic growth, and that pollution was the price to be paid. This would support the sociological research noted earlier that the more powerful an organization, the more it could resist external pressures. Both American and German firms responded to threat of regulations by arguing for more detailed studies of the problem, owing to scientific uncertainties. Like the Germans, the American firms suggested that pollution incidents and complaints were a matter for local responses, tailored to specific settings, and considered primarily as nuisances rather than as environmental or health hazards. US chemical companies relied just as much as their German counterparts on industry associations and corporatist-style negotiations with the national, regional and local government authorities 
who held discretion over administrative responses to public complaints about pollution. ${ }^{85}$ Uekötter has argued that the key difference between the US and Germany before 1970 was not that industry tried to lobby to shape regulation, but that Americans were more effective at it. This was the case here, when, for example, the efforts by German manufacturers to influence the VDI Clean Air Commission met with little success. ${ }^{86}$

The near-consensus in the literature on the American industry is that this era saw unsatisfactory outcomes, including ineffective policies and outright deceit by the chemical industry itself. Smith's already-cited case study of Du Pont provides a rare exception with its argument that the industry did reasonably well in pursuing solutions to complex policies with conflicting scientific evidence, and in the absence of much interest by either legislators or the public. ${ }^{87}$ The evidence on the German chemical industry seems to broadly support Smith's argument that this kind of policy regime could achieve some positive outcomes, but in retrospect not nearly enough. A survey by the Vereinigung der Grosskesselbesitzer (Association of High-Performance Steam Boiler Owners) showed that the emission of particulate matter in West Germany declined by 27 per cent from 1952 to 1962, even though production had increased by about 130 per cent over that decade. ${ }^{88}$ Both Bayer and Henkel reported reduced pollution loads. Between 1958 and 1972 Bayer's emission of sulphur dioxide declined by 80 per cent, despite a considerable increase in production. ${ }^{89}$ Bayer's management reported the Leverkusen plant's emissions of nitrogen oxides and organic substances were "lower than the concentrations from the traffic on the nearby Autobahn." 90 The achievements appear concrete, but also bounded. The focus was on visible water pollution, dust and odour problems, while wider environmental issues received little attention.

Among the most important of such issues was finding alternatives to active agents which were polluting. Detergents again became central to debates as it emerged that the phosphate compounds used as builders in synthetic detergents, especially sodium 
tripolyphosphate (STPP), were contributing to eutrophication, a process by which water became over-fertilized leading to an excessive growth of algae and other plant life. As more oxygen was consumed by growing and decomposing water vegetation, insufficient oxygen remained for fish life. Lakes began to dry up and die. Although eutrophication occurred naturally, the process usually took tens of thousands of years. The far more accelerated eutrophication that was observed in the 1960s appeared to be related to phosphate detergents, although the scientific evidence was not clear-cut. ${ }^{91}$

Henkel made an early research commitment to finding a workable substitute to the phosphorus issue. Konrad Henkel, who became chief executive in 1961 following the death of his elder brother, showed a new interest in engaging with environmental issues. The grandson of Henkel's founder, he had been trained as a chemist, and worked as a researcher before joining the family business in $1948 .^{92}$ He established an Ecological Research Department in 1964, which immediately started research on the effect of phosphates. The company also began to measure phosphate loads in the Rhine. ${ }^{93}$ These steps were noticeably ahead of Henkel's major European competitor Unilever, which continued to take a reactive approach to the phosphate issue, not committing fully to developing a viable phosphate substitute, and only shifting to low-phosphate formulas when legislation demanded it. In the United States, however, $\mathrm{P} \& \mathrm{G}$ also initially responded as energetically as Henkel to mounting public criticism by undertaking research on substitutes. The firm developed a substitute, nitrolotriacetic acid (NTA), which it started using in 1966, and which became the preferred option of the Soap and Detergent Association until 1970, when it was discovered that NTA had health risks and was banned. ${ }^{94}$ Thereafter the strategies of Henkel and P \& G began to diverge.

\section{Building Green Identities}


During the 1970s Bayer and Henkel, like their American counterparts, encountered a more challenging environment as public opinion became more critical of the chemical industry, and there was a swathe of environmental protection legislation. West Germany emerged as one of the countries where environmental consciousness rose most sharply, but it was far from alone. There was a growing environmental movement in the United States, sparked by the publication of Silent Spring in 1962, and confirmed by the attention received by the first Earth Day on April 22, $1970 .^{95}$

The German press expressed more scepticism about big business and its environmental impact than in the past. In October 1970, the influential national weekly Spiegel ran a title story on "Gesellschaft und Umwelt" ("Society and the Environment") which publicly accused Bayer of polluting air and water. "Sometime we really don't know what more you could want Bayer to do", proclaimed a Bayer advertisement quoted in the article. The article contrasted Bayer's corporate attitude with data that showed that the amount of polluted water released by the company nearly equalled "the effluents of a major town with 2.5 million inhabitants." 96

Criticism was especially vocal at the state level. In November 1968, a CDU politician wrote to the NRW parliament demanding a discussion of the issue of air pollution and the health dangers associated with it. ${ }^{97}$ In response, the state government publicly identified the chemical industry as the main cause of air pollution problems. It promised to monitor pollution levels and inform the public more closely. ${ }^{98}$ In a letter addressed to Bayer, the regional Ministry of Labour and Social Affairs argued that "because of the constantly growing nuisances through air pollution-particularly odour effluents-the Cologne region has moved to the centre of public interest and the interest of parliament. ${ }^{\prime \prime 9}$ The state ministry moved to not only collect data about effluents, but publish them in the press, a strategy Bayer strongly opposed. ${ }^{100}$ The regional Ministry of Labour and Social Affairs became a hotbed of environmental concerns and actions, much to the discomfort of Bayer and Henkel. ${ }^{101}$ This 
paralleled the situation in the United States where, during the early 1970s, it was municipal and state governments which took the lead in banning phosphate detergents. ${ }^{102}$

The NRW government also found new support at the Federal level. In 1969 Willy Brandt was finally elected Chancellor. In the name of his coalition government, which encompassed the SPD and the smaller Liberal Party (FDP), Brandt declared that "the federal government embraces the conviction that protection of nature, and of natural preserves, including animals, must receive more attention." ${ }^{103}$ The German government adopted the principle of precaution (das Vorsorgeprinzip), rather than a specific standard of scientific proof, as the norm by which its environmental legislation would be guided. This was a radical move which few other governments followed. In Britain, for example, legislation tended to follow only on the basis of scientific evidence for environmental harm. ${ }^{104}$

Hans-Dietrich Genscher, an FDP politician who was appointed the Minister of the Interior, embarked on new environmental legislation which extended over the decade, covering issues ranging from aircraft noise and forestry conservation to the use of DDT pesticides. ${ }^{105}$ He also created the Sachverständigenrat für Umweltfragen (Council of Experts for Environmental Questions), an academic consultancy body advising the Bundestag on questions of environmental policy. In 1974, shortly before he transitioned to being Foreign Minister, he created the Umweltbundesamt (Federal Environment Agency), a Federal authority on environmental matters, which provided scientific support to the Federal government, oversaw implementation of environmental laws, and provided public information about environmental protection. ${ }^{106}$

This legislation reflected growing alarm about pollution. In 1970, one survey showed that 44 percent of the German public had stated that they would be willing to make personal sacrifices for environmental protection. By 1974, the number had increased to 70 percent. $^{107}$ Another survey showed that the chemical industry was considered a major culprit of 
environmental damage. The more educated the respondent, the more critical they were of industry. ${ }^{108}$ Environmental concerns spanned the political spectrum. In 1975 it was Herbert Gruhl, a CDU parliamentarian, who published a best-selling book entitled The Plundering of the Planet, which criticised unrestrained economic growth and the destruction of the ecosystem. ${ }^{109}$

The criticism of the chemical industry in particular was as virulent in the United States as in West Germany, and in both countries industry leaders considered it unfair. "A climate of hysteria has been created, in which an objective discussion is not possible anymore", reflected Konrad Henkel in a speech in $1971 .{ }^{110}$ In an internal discussion he called the issue a "witch hunt" against the chemical industry. ${ }^{111}$ In the United States, P \& G executives considered the media criticism against phosphates "emotional, political, and, at times, quite irrational."112

Despite the similarities, the strategies of the German and American companies began to diverge. In the United States, the creation of the Environmental Protection Agency (EPA) in 1970 resulted in an increasingly stringent regulatory regime, at least until the Reagan Administration in 1981 sought to reverse the power of the agency. There were growing numbers of lawsuits against chemical firms from environmental activists, and strategies became focused on regulatory compliance. The chemical companies felt defensive and embattled, with the trade journal Chemical Week complaining of the anti-industry and antitechnology views of critics in the media and elsewhere. ${ }^{113}$ Public relations were employed as a strategy to, at best, portray the industry's environmental efforts in their best possible light, and at worse to deliberately cover up known and harmful environmental impacts. ${ }^{114}$ Greer and Bruno have argued that the strategies of denial, and lobbying, during the 1970s where the first stage of a process which had evolved by the late 1980s into a more elaborate "green washing," by US corporations, which involved the simultaneous co-opting of environmentalist rhetoric with strategies to weaken environmental standards. ${ }^{115}$ 
In contrast, in West Germany, the senior managements of Henkel and Bayer shifted to more proactive strategies. During the mid-1960s Henkel, advised by the American consultancy Stanford Research Institute, had begun to invest resources in enhancing the public image of the company in general. In 1965 a campaign started to link the name of Henkel with cleanliness. Considerable emphasis began to be put on the firm's long tradition in Germany, as well as its family ownership. ${ }^{116}$

In 1969, Friedrich Bohmert, the head of corporate public relations, started to further reshape the firm's communication strategies. Bohmert, who had worked as a journalist for the popular weekly magazine $H \ddot{o r} z u$, asserted that Henkel was an integral part of society, and that it needed to be open to the public and the press. He convinced his colleagues that the communication between company and society was an important task for senior management, and pleaded for a systematic, proactive and all-encompassing strategy. His policy was based on the principle of acting instead of reacting, and informing instead of denying and defending. ${ }^{117}$ In a new corporate image campaign run in 1972/73, Henkel emphasised its new motto of "Industry and Society." Bohmert was awarded one of the most prestigious professional prizes, the "Goldene Brücke," for the campaign by the German Public Relations Society. ${ }^{118}$

Henkel redoubled its efforts to build an attractive environmentalist corporate image after the earlier attempts had limited effect. In 1970 the management board already predicted that the pressures exerted by environmental groups would lead to legislation and regulations that "may threaten the survival of our company." ${ }^{119}$ In the following year, the company complemented the existing corporate identity with the new slogan of "Henkel for Environmentally Friendly Products and Operations." An internal Commission for Environmental Protection was created in 1971 as a central decision-making body on environmental matters. Peter Berth, who held a chemistry doctorate and had worked in 
research at the company since the 1950s, was appointed as chairman of the new unit, which was placed under the central management. It was entrusted with "the setting of priorities for the work of carrying out the required defensive and offensive actions" and with "centralizing all internal company activities in this area." ${ }^{120}$

The intensity of the political and public criticism in Düsseldorf/Holthausen and NRW heightened environmentalist concerns within Henkel. The management decided to engage the local community more directly. In November 1971, residents were invited to join the company's managers for a "dialogue with neighbours" about environmental protection. Held on a Sunday at the main company headquarters in Holthausen, the event was led by Bohmert and intended to break "the much criticized silence about environmental protection among industrial firms." ${ }^{121}$ A series of short films and presentations displayed Henkel's efforts and plans to combat environmental pollution. The event met with both positive and more sceptical responses. Internally, Henkel's management emphasized its hope that "irrational fears" about its activities would yield to reasonable discussions about intelligent solutions to problems. ${ }^{122}$

The event raised expectations which were not immediately met. As a result, when Henkel did not follow up with other public events, ten citizens from the local neighbourhood took action in January 1974 with an initiative named "Protect the environment from Henkel." By March, it had attracted such political momentum that an official meeting between activists and representatives from every political party was held. A major press campaign against Henkel was launched, and the activists demanded an environmental hearing by the Düsseldorf city government. The hearing was held in December. Henkel was obliged to defend its efforts to address pollution problems. ${ }^{123}$ This prompted the company to engage in further efforts at local outreach. These included the launch of Henkel Umwelt Blick, a magazine for the citizens of Düsseldorf and in particular for the neighbors of the Henkel plant, in which the company presented its latest research on environmental protection. It had a circulation of $50,000 .^{124}$ 
The literature on the use of public relations in the American chemical industry, where it appears a prime example of selective disclosure on environmental matters, raises scepticism about the genuineness of Henkel's emergent new "environmentally friendly" identity. Yet the internal records of the company suggest that top management did take environmental issues seriously. The head of corporate Research \& Development and a member of the operating management, Dr. Arnold Heins, gave a copy of the 1972 Club of Rome report on The Limits to Growth to each participant at Henkel's Technical Detergent Conference in 1972, and a special session was devoted to its discussion. This session identified the creation of the EPA in the United States, and the announcement by the European Council of the European Conservation Year, in 1970 as events which had a strong effect on the public awareness of environmental problems in West Germany. ${ }^{125}$

Konrad Henkel also sent a strong signal both within and outside of the company about the direction it was taking on the environmental questions when he declared at a major industry event in Berlin in 1972 that "we have all relied too much on the capacity of nature to regenerate itself. Stuck in our belief in progress, we have not paid enough attention to the undesirable side effects of progress. This must change." ${ }^{126}$ Henkel was at that time the chairman of the German Chemical Industry Association. When the senior management of the firm met at the end of 1972, Henkel chaired a meeting which concluded that taking "environment protection issues ... into account has priority over opportunities to take advantage of short-term sales- and profits." ${ }^{127}$

The company began self-identifying as an organization whose responsibility to protect the environment had become "general", as "environmental consciousness has become completely generalized and common in our society." The responsibility of companies, the management board concluded in 1973 , had to extend to the protection of society as a whole on "the widest levels." ${ }^{128}$ The senior management also sought to engage employees in environmental issues. The company designed an environmental logo with voluntary input by 
more than 400 employees, and regular competitions for making Henkel greener were instituted. The firm implemented a "Environmental Consciousness" plan (Umweltbewusstsein mit Aktionsplan) in 1974. On the management level, this plan received its own working group, which had a representative on the management board.

Although Henkel's initial attempts to develop more effective outreach to the environmentalist community stumbled, the firm continued to seek to translate their environmentalist discourse into real corporate policies. Following the example set by the Federal government, and anticipating state regulation along the same lines, Henkel adopted the principle of precaution (Vorsorgeprinzip) and the polluter pays principle (Verursacherprinzip) in its definition of environmental responsibility. In contrast, the American companies at this time were still devoted to the tactic of keeping products on market, and emissions at current levels, while awaiting further studies or until mandated by regulators. Henkel adopted a "principle of cooperation" (Kooperationsprinzip), which Berth defined as "trust-based cooperation" among scientists from different industries and universities, and with other companies and government authorities on the domestic, regional, and international level. ${ }^{129}$ A new Environmental Coordination Office was created to serve as the coordinating department.

Berth's new department took responsibility for the coordination of activities aimed at developing new products to substitute for raw materials perceived environmentally damaging. Henkel's most pressing concern was to find a substitute for phosphates. In 1973, Henkel filed for an initial patent for the synthetic zeolite builder Sasil, an environment-friendly alternative to phosphates. ${ }^{130}$ In the same year, Helmut Sihler, a partner in Henkel and Chairman of the Central Board of Management, spoke publically about the trade-off raised for a firm by the issues of phosphates - the tension between providing consumers with a product using 
phosphates that they might prefer as a more effective detergent, and meeting wider societal needs by providing a zero-phosphate product which was better for the environment. ${ }^{131}$

Sihler's observation was made within the context of a global view of the issues. During regular visits to American and Japanese competitors, Henkel's managers explored how companies dealt with environmental questions, and if these countries might develop into markets for their new zeolite builder. In Japan, the visitors noted the "cleanliness of the Japanese people," but also the complete neglect of air and water pollution control. Henkel managers observed the rising attention to environmental issues in the United States. ${ }^{132}$ Disasters outside Germany also continued to raise the profile of the environmental issue for Henkel and other German firms. A major industrial accident in a chemical manufacturing plant in Seveso, north of Milan, in July 1976 triggered a new wave of public criticism of the chemical industry in Germany, and resulted in a widely circulated book entitled "Seveso is everywhere," which identified, in the words of the subtitle, "the deathly risks of the chemical industry." 133

The upshot was that although both Henkel and P \& G shared an understanding that there was a trade-off between protecting the environment providing a zero phosphate product and meeting consumer demand for a maximally effective cleaning product, two corporate strategies now diverged. Henkel insisted that, on environmental grounds, a future of zero phosphate detergents was a desirable goal. P \& G, which had filed a patent for a synthetic zeolite builder at the same time as Henkel, continued to downplay the role of detergents as a source of phosphate in the natural environment, and argued that reducing or eliminating phosphates in detergents would not effectively address the problem. P \& G advocated the installation of municipal so-called tertiary treatment plants as preferable to removing phosphates from detergents. ${ }^{134}$ Henkel argued against prioritizing the removal of phosphates through tertiary water treatment, and instead committed to more research until a zero phosphate detergent was found that prevented pollution. ${ }^{135}$ 
P \& G continued to reformulate its brands with phosphate-free zeolite when it was obliged to, but otherwise employed phosphates, sometimes putting them back into brands when public pressure waned. It was only in 1993, after bans and restrictions on STPP had been enacted in many US states and in Canada, that $\mathrm{P} \& \mathrm{G}$ permanently abandoned phosphates in its North American brands. It continued to sell brands with phosphates in other markets. ${ }^{136}$ In contrast, in 1983, Henkel's first Zero P detergent, was launched under the brand Dixan, employing a mixture of zeolite with polycarboxylate. Henkel introduced a phosphatefree "green" Persil in Austria, Netherlands and Switzerland two years later, and in 1986 Persil transitioned to a 100 per cent phosphate-free formulation in Germany. ${ }^{137}$ These phosphatefree brands preceded any legislation. In 1988, the Germany detergents industry agreed on a voluntary total phosphate ban. ${ }^{138}$

Henkel further institutionalized its environmental corporate strategy under the name "Environment, Consumer Protection, and Safety" in $1982 .{ }^{139}$ Five years later, in the wake of going public, Henkel published a set of "Corporate Guidelines", placing "environmental protection on the same level as the generation of profits as corporate objectives." ${ }^{140}$ Although Henkel managers might have initially perceived a tension between consumer desires and helping the environment, by then it had become apparent that a green image was a way to add value in the saturated market for detergents. During the 1980s managers at Henkel's detergents competitor Unilever expressed annoyance that Henkel, as well as P \& G, had achieved greater acclaim for being "green" than it had, even though their products and processes by then seemed not dissimilar in their environmental impact. ${ }^{141}$ However it was noteworthy that Henkel pushed forward making only phosphate-free detergent at a time when both international competitors were, in some cases, reverting to the use of STPP.

Bayer's transition to a "green giant" paralleled that of Henkel, at least to some extent. The firm was far more diversified than Henkel, and was not a producer of a product like 
detergents which was a visible symbol of environmental concerns, yet it also felt pressured to respond to the increasing criticism by the NRW state government, the citizens of Leverkusen, and others. The staff of the AWALU unit was increased from 100 to 207 between 1969 and 1971, and reached 480 in $1974 .{ }^{142}$ AWALU stipulated in that year in an internal document that new products had to be designed as to meet the requirements of environmental protection. $^{143}$

In 1974 Herbert Grünewald's appointment as Chair of the Management Board resulted in a new commitment to environmental spending. Grünewald had been responsible for Bayer's human resources and social affairs before becoming Chair, and had formulated strong views on corporate social responsibility. On the environment, Grünewald's views mirrored those of the American chemical industry in some respects. He publically complained about the negative impact on profits and employment of government environmental legislation. ${ }^{144}$ He opined to journalists his view that his firm "could not win" in environmental matters, because Bayer's enemies "would still throw dead fish from the river Elbe in front of our doors." ${ }^{145}$ However, Grünewald also made it clear, externally and internally, that correct environmental policies were a corporate responsibility, and that damage control was not sufficient. "Regarding environmental damage," he told Der Spiegel in 1977, "we do not just want to repair it, we want to avoid it from the outset." In the same interview, Grünewald argued that environmental investments were an innovation opportunity for the firm. "When you introduce research for environmental protection," he noted, "you also create more value." 146 This was an early articulation of the now widespread phenomenon which Dauvergne and Lister have described as "eco-business" - the use of sustainability strategies by large firms to make efficiency gains and enhance brand value. ${ }^{147}$ In 1975 the AWALU was renamed Environmental Protection/AWALU, and the number of employees increased further 
reaching 675 in $1980 .{ }^{148}$ As Table 2 shows, the company's investments environmental protection rose through the 1970 s, although it fell back in the wake of the second oil crisis. ${ }^{149}$

Table 2: Bayer's Investments in Plants for Environmental Protection

\begin{tabular}{|c|c|c|c|c|}
\hline & $\begin{array}{l}\text { Investments in plants for environmental } \\
\text { protection (in million D-Mark) }\end{array}$ & $\begin{array}{l}\text { Percentage of total } \\
\text { investments (\%) }\end{array}$ & $\begin{array}{l}\text { Cost of operation (in } \\
\text { million D-Mark) }\end{array}$ & $\begin{array}{l}\text { Number of employees } \\
\text { in AWALU }\end{array}$ \\
\hline 1971 & 65 & & 150 & \\
\hline 1972 & 54 & & 160 & 300 \\
\hline 1973 & 74 & 11 & 173 & 350 \\
\hline 1974 & 111 & 13 & 220 & 480 \\
\hline 1975 & 99 & 14 & 250 & 500 \\
\hline 1976 & 109 & 17 & 286 & \\
\hline 1977 & 121 & 18 & 322 & 552 \\
\hline 1978 & 133 & 22 & 359 & 574 \\
\hline 1979 & 182 & 24 & 410 & 600 \\
\hline 1980 & 165 & 18 & 485 & 675 \\
\hline
\end{tabular}

Sources: BAL Bayer AG Annual Reports 1971-1980. BAL Ingenieurverwaltung AWALU 1973-1988, Jahresberichte der Abt LE Umweltschutz/AWALU. 
Waste water management was a central focus. A decade before Grünewald's appointment Bayer had launched a joint venture with the city of Leverkusen and the regional government to construct and operate a plant to treat both industrial effluents and domestic sewage. Begun in 1966, the first part of the project was completed in 1971. It employed state of the art technology, although both the noise and the odour generated complaints. ${ }^{150}$ In 1971 , Bayer also opened Europe's largest industrial wastewater plant in Dormagen in cooperation with its German joint venture with BP, Erdölchemie GmbH. In 1975, another huge wastewater plant in Uerdingen was opened. ${ }^{151}$ Bayer received an environmental protection prize from the Friedrich Flick Foundation in 1975 for the improvement of analysis equipment to monitor emissions. ${ }^{152}$

Among Bayer's major innovations was the development of the Tower Biology facility in Leverkusen in 1979. This facility comprised four hundred feet high towers, and was the first of its kind allowing biological waste water treatment in a small area with little noise and odour, and using only one-quarter of the energy which previous systems had employed. The facility treated waste from both the Bayer factory and the city. The technology was employed at the same time in Bayer's factory at Thane in Maharashhtra in India, and later adopted in other industries, including brewing. ${ }^{153}$ Overall, in 1981, Bayer spent over two-thirds of its total investment in environmental protection on water cleaning facilities. ${ }^{154}$ Company data showed that between 1977 and 1987 the amount of heavy metal elements in Bayer's wastewater fell by between 85 and 99 per cent, while pollutant emissions in the atmosphere declined by 80 per cent. ${ }^{155}$

Across the range of the firm's businesses, there was a pattern of incremental investments. In 1963 Bayer had implemented a so-called double-contact process for a more efficient and environmentally conscious production of sulphuric acid used for mineral processing, fertilizer manufacturing, oil refining, wastewater processing, and chemical synthesis. The firm then invested in improving the process year after year, with momentum 
increasing over time. There were significant investments in improving this process over the following two decades. ${ }^{156}$ There was similar incremental investments in improving the environment performance of the Roskydal product line of unsaturated polyester resins, which especially after 1980 made the product odourless and ever- more environmentally friendly. ${ }^{157}$

While Bayer was making improvements in reducing its negative environmental impact, there was also a new interest in building the firm's green credentials in the corporate image. "Adequate marketing is almost as important as an environmentally neutral production", argued the head of AWALU in 1972. ${ }^{158}$ Bayer introduced a new slogan "Bayer researches for environmental protection" and a new logo, a green leaf, during that year. Television advertisements informed the public about Bayer's environmental protection using the new slogan and logo. ${ }^{159}$ In an internal document in 1972, Bayer managers argued that it was necessary to engage in more active marketing efforts to counter the "industry-hostility" that made conflicts with the neighbours more severe than they had been in the past. ${ }^{160}$ AWALU selected a scientist for the environmental public relations who was the contact person for representatives of the media. The latter, members of the AWALU unit argued in 1972, were increasingly scientists themselves, for whose inquiries Bayer needed an equally well-educated spokesperson. ${ }^{161}$

The concern to bolster the firm's positive environmental image extended below the senior management. In 1973 a representative of the workers council, Heinz Jacobi, suggested to the management board that Bayer should make a bigger effort showcasing its activities in environmental protection by organizing an exhibition, and in particular engaging with school children. The exhibition indeed took place in June 1974, and included the head of AWALU. ${ }^{162}$

In 1974, following Grünewald's appointment as Chair, a sub-unit within AWALU was created which was dedicated to public relations. It organized an annual press conference 
concerning environmental protection with members of the management board as speakers, three to four smaller press conferences at the local level, as well as information and images for the press whenever necessary. The unit was meant to remain in constant contact with journalists "to influence or even stop negative press regarding Bayer in critical situations", as Dr. Meyer, the head of the sub-unit pointed out in an internal briefing. ${ }^{163}$

Bayer was already engaged in community outreach. It created a competition for school pupils and university students to engage them in questions of environmental protection. It offered "open-door days" for people interested in Bayer's environmental activities and printed brochures with the title "Bayer does more." The company also created an internal competition for its employees to choose the best ideas about recycling in 1972 - an event that one manager was sure would "improve the Bayer image significantly." ${ }^{164}$ For its customers, it offered "green consulting" by informing them about the environmental impact of products and processes. In 1973, a booklet was published describing 60 environmentally-friendly procedures and products at Bayer. ${ }^{165}$

In 1976 Bayer conducted a consumer survey on the chemical industry and environmental protection. Overall, 94 per cent of the respondents considered environmental protection important, while an impressive 61 per cent mentioned Bayer as one of the chemical companies making a positive contribution to environmental protection. ${ }^{166}$ Bayer also received more positive press coverage over time. In a 1978 article, the national Zeit called Bayer "a green giant," noting its transformation after years of bad publicity. ${ }^{167}$ Bayer invested heavily in communicating with the media. In 1980, it offered a seminar for journalists of regional and national newspapers with the title "Research, Production - Safe and Environmentally Sound." ${ }^{168}$ While Henkel's senior management, by the 1970 s, was articulating strong views on environmental issues, and was prepared to move beyond regulatory compliance, as in the case of phosphates, Bayer more clearly fits the Dauvergne and Lister eco-business model. 
Grünewald clearly understood that sustainability could be a source of value and credibility for the firm. Bayer was not engaged in green washing - there were real environmental gains in reducing the harmful effects of pollution and waste - and it was engaged like its US counterparts in trying to fight environmental regulation. However the strategy was fundamentally aimed at the "sustainability of big business, not sustainability of people and the planet." 169

\section{Conclusions}

This working paper has traced the evolution of the corporate environmental strategies of Henkel and Bayer to post-war concerns about the environment. Both German firms have been called, or self-identified, as "eco-pioneers" and "green giants." Their strategies appear to contrast with most interpretations of the environmental strategies, or lack of them, of the American chemical industry at this time.

It has been suggested that before the 1970s the environmental policies of Bayer and Henkel were not different, for better or worse, from their peers in the United States. Both firms were long-established polluters in an industrialized region notorious for stinking. The nature and timing of complaints about pollution in the two countries followed similar patterns. The chemical industry's initial response in both cases was to argue that their enterprises were necessary to economic progress, that pollution was the price to be paid, and that more research was necessary. In both countries firms relied on industry associations and corporatist-style negotiations with local, regional and national authorities. Especially in the specific issue of detergent phosphates in water eutrophication, state and municipal governments in both countries were the first to move away from this pattern toward more adversarial and stricter regulatory threats. 
During the 1970s, however, the two German firms really did start to invest more in environmentally sustainable products, processes and strategies. While the US chemical industry remained defensive and focused on legal compliance, there was a greater proactivity among the German firms. The managements, Henkel in particular, moved beyond the technical compliance seen in the United States, and both firms launched assertive, proactive campaigns to build images as "green giants." While American firms often employed public relations to divert attention from problems, or even to mislead, Bayer and Henkel used fallout from criticism as opportunities for changes in corporate culture aimed at a positive bond with consumers based on new "green” brand identities. During the 1970s Bayer's management articulated views that sustainability could result in real commercial benefits to the firm, similar to recent descriptions of "eco-business" strategies.

The working paper has examined why German strategies diverged from those seen in the United States. It has found little support for explanations resting on alleged differences between German and American models of capitalism. However other home country influences are discernible. In Germany, Henkel and Bayer were initially spared criticism because of their perceived importance in rebuilding the shattered German economy, but by the 1970 s there were rising environmental concerns across a wide section of the German population, as evidenced by the election of Green Party representatives to the Bundestag in 1983. There were significant environmental activist movements in the United States also, but they were not powerful enough to win many public offices. During the early 1980s, as the Green Party entered the Bundestag, the Reagan administration was trying to emasculate the EPA.

However, this was at least as much of a regional story than a national one. The significant regulatory, political and other differences in many countries, perhaps especially Germany and the United States, are regularly ignored in the variety of capitalism literature, 
including Mikler's study of the greening of the automobile industry. Yet the regional embeddedness of Bayer and Henkel in NRW emerges as an important determinant for investments in green products and processes. The firms had deep reputational stakes invested in their region. This sharpened the impact of protests held outside their head offices, and local politicians criticising and legislating about pollution. The reputation of Henkel, a family firm held to embody the strength of German capitalism, and which had invested in a corporate image associated with cleanliness, was highly vulnerable to local residents and the local government blaming it for foamy rivers and bad smells. The reputation of Bayer, the pride of the German chemical industry, manufacturer of aspirin and whose logo illuminated Leverkusen, was equally vulnerable to being accused of creating "car-pox" and killing fish. Initially this "domain-specific visibility" did not result in a marked divergence from strategies seen elsewhere, but its effect appears to have been both real and cumulative. By the 1970s, and after the Federal government had also become engaged in environmental issues, a new generation of corporate leaders such as Konrad Henkel, Herbert Grünewald and Friedrich Bohmert had concluded that more reactive strategies were needed to fulfil societal expectations. They were savvy enough to understand that investing in environmental sustainability could provide an opportunity to create value for the firm, and that selfidentifying as eco-pioneers had commercial as well as reputational benefits, provided that the image reflected genuine policies and processes. 


\section{Bibliography}

\section{Unpublished material}

Bayer Archives Leverkusen (BAL)

Henkel Konzernarchiv Düsseldorf Holthausen (HA)

\section{References}

Abelshauser, W. Deutsche Wirtschaftsgeschichte seit 1945. München: Beck, 2005.

Andersen, M.S. and D. Liefferink. European Environmental Policy: The Pioneers. Manchester: Manchester Univ. Press, 1997.

Bansal, P., \& Roth, K. "Why Companies Go Green: A Model of Ecological Responsiveness." Academy of Management Journal, 43, 4 (2000): 717-736

Beeton, A.M., "Eutrophication of the St. Lawrence Great Lakes." in Man's Impact on Environment, ed. Detwyler, T.R. New York: McGraw-Hill Book Co., 1971.

Berghahn, V.R. and S. Vitols, eds., Gibt es einen deutschen Kapitalismus?: Tradition und Globale Perspektiven der Sozialen Marktwirtschaft. Frankfurt/Main, New York: Campus, 2006.

Berghoff, H. "The End of Family Business? The Mittelstand and German Capitalism in Transition, 1949-2000." Business History Review 80 (2006): 263-295.

Berghoff, H. and M. Mutz. "Missing Links? Business History and Environmental Change." Jahrbuch für Wirtschaftsgeschichte 2 (2009): 9-22.

Bergquist, A.-K. and K. Söderholm. "Green Innovation Systems in Swedish Industry, 19601989." Business History Review 85 (2011): 677-698.

"Blauer Himmel Über Der Ruhr." Der Spiegel 33, 9 August 1961: title and 22-33.

Boullet, D. Entreprises et environnement en France de 1960 à 1990: Les Chemins d'une prise de conscience. Genève: Droz, 2006.

Bramwell, A. Ecology in the 20th Century. A History. New Haven: Yale University Press, 1989.

Brüggemeier, F.-J. Das unendliche Meer der Lüfte: Luftverschmutzung, Industrialisierung und Risikodebatten im 19. Jahrhundert. Essen: Klartext, 1996.

Büschenfeld, J. Flüsse und Kloaken: Umweltfragen im Zeitalter der Industrialisierung (1870 - 1918). Stuttgart: Klett-Cotta, 1997.

Bundesministerium der Justiz. "Gesetz Über Detergentien in Wasch-Und Reinigungsmitteln, 5 September 1961." Bundesgesetzblatt 72 (1961), Teil 1: 1653-1654.

Cairncross, F. Green, Inc.: A Guide to Business and the Environment. Washington, DC: Island Press, 1995.

Carroll, A.B., Lipartito, K.J., Post, J.E, and Werhane, P.H. Corporate Responsibility: The American Experience. Cambridge: Cambridge University Press, 2012.

Cassis, Y. Big Business: The European Experience in the Twentieth Century. Oxford: Oxford University Press, 1997.

Chandler, A.D. Shaping the Industrial Century: The Remarkable Story of the Modern Chemical and Pharmaceutical Industries. Cambridge, MA: Harvard University Press, 2005.

Colten, C.E and P.N. Skinner, The Road to Love Canal: Managing Industrial Waste before EPA, Austin: University of Texas, 1996.

Dalton, R.J., "The Environmental Movement in Western Europe," in ed. S. Kamieniecki, Environmental Politics in the International Arena: Movements, Parties, Organizations, and Policy, Albany: SUNY Press, 1993.

Dalton, R.J. The Green Rainbow: Environmental Groups in Western Europe. New Haven: Yale University Press, 1994. 
Dauvergne, P. and Lister, J. Eco-Business: A Big-Brand Takeover of Sustainability. Cambridge, MA: MIT Press, 2013.

Dore, R.P. Stock Market Capitalism-Welfare Capitalism: Japan and Germany Versus the Anglo-Saxons. Oxford: Oxford University Press, 2000.

Dyer, D., F. Dalzell, and R. Olegario. Rising Tide: Lessons from 165 Years of Brand Building at $P \& G$. Boston, Mass.: Harvard Business School Press, 2004.

Feldenkirchen, W. and S. Hilger. Menschen und Marken. 125 Jahre Henkel 1876-2001. Herausgegeben im Auftrag der Henkel KGaA von Ernst Primosch und Wolfgang Zengerling. Düsseldorf: Henkel KGaA, 2001.

Freter, H.W., "Marketing und Wohlfahrtsökonomie: Podiumsdiskussion an der Universität Münster," in Marketing Heute und Morgen: Entwicklungstendenzen in Theorie und Praxis, ed. Meffert, H. Wiesbaden: Gabler, 1975.

Gassdorf, D. and Henkel KGaA. It All Started with Water Glass: 100 Years of Revolutionary Research at Henkel. Düsseldorf: Henkel KGaA, 1996.

Gerhard, G., "Breeding Pigs and People for the Third Reich," in How Green Were the Nazis?, ed. Brüggemeier, F.-J., M. Cioc and T. Zeller. Athens: Ohio University Press, 2005.

"Gesellschaft Und Umwelt." Der Spiegel 41, 5 October 1970: 74-96.

"Gold Aus Gift: Seveso, Hch und eine gute Tradition der Chemie." Zeit 16, 13 April 1979.

Golub, J., ed., New Instruments for Environmental Policy in the EU. London: Routledge, 1998, http://www.gbv.de/dms/bowker/toc/9780415156967.pdf.

Greer, J. and K. Bruno, Greenwash: The Reality behind Corporate Environmentalism. New York: Apex Press, 1996.

Gruhl, H. Ein Planet wird geplündert: Die Schreckensbilanz unserer Politik. Frankfurt am Main: Fischer, 1975.

Guha, R, Environmentalism. A Global History. New York; Longman, 2000.

Hall, P.A. and D. Soskice, "An Introduction to Varieties of Capitalism,"in Varieties of Capitalism. The Institutional Foundations of Comparative Advantage, eds. Hall, P.A. and D. Soskice. Oxford: Oxford University Press 2001, 1-68.

Hayes, P. Industry and Ideology: IG Farben in the Nazi Era. Cambridge: Cambridge University Press, 1987.

Heilmann, K. Die betrogene Gesellschaft: Kommunikation im Informationszeitalter. Zürich: Orell Füssli, 1990.

Hilger, S. "Amerikanisierung" deutscher Unternehmen: Wettbewerbsstrategien und Unternehmenspolitik bei Henkel, Siemens und Daimler-Benz (1945/49-1975). Stuttgart: F. Steiner, 2004.

Hilger, S., "Reluctant Americanization? The Reaction of Henkel to the Influences and Competition from the United States, " in German and Japanese Business in the Boom Years, eds. Kudo, A., Kipping, M. and Schröter, H.G. London: Routledge, 2004.

Hilger, S., "Umweltschutz als unternehmerische Herausforderung: Das Beispiel des Düsseldorfer Chemieunternehmens Henkel nach dem Zweiten Weltkrieg," in Das Heute hat Geschichte: Forschungen zur Geschichte Düsseldorfs, des Rheinlands und darüber hinaus, ed. Mauer, B. Essen: Düsseldorfer Geschichtsverein e.V., 2012: 41936.

Hoffman, A.J. From Heresy to Dogma: An Institutional History of Corporate Environmentalism. Stanford, Calif.: Stanford Business Books, 2001.

Hoffmann, W. "Der Grüne Riese Am Rhein." Zeit 8 Dec. 1978.

Hollingsworth, J.R., "Continuities and Change in Social Systems of Production: The Cases of Japan, Germany, and the United States," in Contemporary Capitalism: The Embeddedness of Institutions, eds. Hollingsworth, J.R. and R. Boyer. Cambridge: Cambridge University Press, 1997: 265-310. 
Hopfenbeck, W. The Green Management Revolution: Lessons in Environmental Excellence. New York: Prentice Hall, 1993.

Hünemörder, K.F. Die Frühgeschichte der globalen Umweltkrise und die Formierung der deutschen Umweltpolitik (1950 - 1973). Stuttgart: Steiner, 2004.

Jeffreys, D. Aspirin: The Remarkable Story of a Wonder Drug. New York, NY: Bloomsbury, 2004.

Jones, G. Renewing Unilever: Transformation and Tradition. Oxford: Oxford Univ. Press, 2005.

Jones, G., "Entrepreneurship in the Natural Food and Beauty Categories before 2000: Global Visions and Local Expressions." Harvard Business School Working Paper 13-024 (2012).

Jones, G. "Debating the Responsibility of Capitalism in Historical and Global Perspective." Harvard Business School Working Paper, 14-004, July 2013.

Jungkind, T. Risikokultur und Stöfallverhalten der chemischen Industrie. Stuttgart: Franz Steiner Verlag, 2013.

Kehoe, T. "Merchants of Pollution? The Soap and Detergent Industry and the Fight to Restore Great lakes Water Quality, 1965-1972.“ Environmental History Review, 16, 2 (1992): 21-46.

Kimminich, O., H. Lersner, and P.-C. Storm. Handwörterbuch des Umweltrechts: Hdur. 2 vols. Berlin: E. Schmidt, 1986

Kleinschmidt, C. Der produktive Blick: Wahrnehmung amerikanischer und japanischer Management- und Produktionsmethoden durch deutsche Unternehmer 1950 - 1985. Berlin: Akad.-Verl., 2002.

Kloepfer, M., C. Franzius, and S. Reinert. Zur Geschichte des deutschen Umweltrechts, Schriften Zum Umweltrecht. Berlin: Duncker \& Humblot, 1994.

Knud-Hansen, C., "Historical Perspective of the Phosphate Detergent Conflict," in Working Paper 94-54, Fall 1993 Natural Resources and Environmental Policy Seminar of the University of Colorado Interdisciplinary Graduate Certificate Program in Environmental Policy and the Conflict Resolution Consortium at the University of Colorado 1994.

Koch, E.R. and F. Vahrenholt. Seveso ist überall - Die tödlichen Risiken der Chemie. Köln Kiepenheuer \& Witsch, 1978.

"Konrad Henkel Ist Tot." Managermagazin 26 April (1999).

Lampe, M. and G. Gazda. "Green Marketing in Europe and the United States: An Evolving Business and Society Interface." International Business Review 4 (1995): 295-312.

Lee, B.W. and K. Green. "Towards Commercial and Environmental Excellence: A Green Portfolio Matrix." Business Strategy and the Environment 3 (1994): 1-9.

Lehmann, H.G. Deutschland Chronik 1945 bis 2000. Bonn: Bundeszentrale für Politische Bildung, 2002

Lindner, S.H. Inside IG Farben: Hoechst During the Third Reich. Cambridge: Cambridge University Press, 2008.

Lubinski, C. "Path Dependency and Governance in German Family Firms." Business History Review 85 (2011): 699-724.

Markowitz, G. and D. Rosner, Deceit and Denial: The Deadly Politics of Industrial Pollution. Berkeley: University of California Press, 2002.

Mann, T. "Lösung der Umweltprobleme in der chemischen Industrie." Lenzinger Berichte 40 (May 1976): 37-44.

Marquis, C. and Toffel, M.W. "When Do Firms Greenwash? Corporate Visibility, Civil Society Scrutiny, and Environmental Disclosure," Harvard Business School Working Paper 11-115 (December 20, 2012) 
McGucken, W. Lake Erie Rehabilitated: Controlling Cultural Eutrohication, 1960s-1990s Akron: University of Akron Press, 2000.

Mikler, J. Greening the Car Industry: Varieties of Capitalism and Climate Change Cheltenham: Edward Elgar, 2009.

Moeller, W. and Winkler. K. "The Double Contact Process for Sulfuric Acid Production." Journal of the Air Pollution Control Association 18 (1968), 324-325.

Mutz, M. Umwelt als Ressource: Die sächsische Papierindustrie, 1850-1930, Göttingen: Vandenhoeck \& Ruprecht (forthcoming.)

Okhmatovskiy, I. and David, R. J. "Setting Your Own Standards: Internal Corporate Governance Codes as a Response to Institutional Pressure," Organization Science, 23, 1 (2012): 155-176.

Osterloh, J. "'Diese Angeklagten Sind Die Hauptkriegsverbrecher.' Die KPD/SED und die Nürnberger Industriellen-Prozesse 1947/48," in NS-Prozesse und deutsche Öffentlichkeit. Besatzungszeit, Frühe Bundesrepublik und DDR, ed. Osterloh, J. and C. Vollnhals. Göttingen: Vandenhoeck \& Ruprecht, 2011: 107-30.

Raasch, M. "Wir Sind Bayer": Eine Mentalitätsgeschichte der deutschen Industriegesellschaft am Beispiel des rheinischen Dormagen, 1917-1997. Essen: Klartext, 2007.

Rosen, C.M. "The Business-Environmental Connection." Environmental History 10 (2005): 77-79.

Rosen, C.M. "Businessmen against Pollution in Late Nineteenth Century Chicago." Business History Review 69 (1995): 351-367.

Rosen, C.M. and C.C. Sellers. "The Nature of the Firm: Towards an Ecocultural History of Business." Business History Review 73 (1999): 577-606.

Ross, B. and Amter, S. The Polluters: The Making of our Chemically Altered Environment. Oxford: Oxford University Press, 2010.

Schöne, M. Aus der Geschichte der P3-Produkte und Verfahren zur Reinigung, Entfettung und Desinfektion. Düsseldorf: Henkel, 1970.

Sluyterman, K. "Royal Dutch Shell: Company Strategies for Dealing with Environmental Issues." Business History Review 84 (2010): 203-226.

Smith, J.K. "“Turning Silk Purses into Sows' Ears: Environmental History and the Chemical Industry." Enterprise \& Society 1 (2000): 785-812.

Souder, W. On a Farther Shore: The Life and Legacy of Rachel Carson. New York: Crown Publishers, 2012.

Spector, B. "Business Responsibilities in a Divided World': The Cold War roots of the Corporate Social Responsibility Movement." Enterprise \& Society 9, 2 (2008): 314336.

Staats, C. Die Entstehung des Bundes-Immissionsschutzgesetzes vom 15. März 1974. Frankfurt/Main: P. Lang, 2009.

Streeck, W., "German Capitalism: Does It Exist? Can It Survive?" in Political Economy of Modern Capitalism: Mapping Convergence and Diversity, ed. Crouch, C. and W. Streeck. London, Thousand Oaks, Calif.: Sage, 1997: 31-54.

Uekötter, F. The Age of Smoke: Environmental Policy in Germany and the United States, 1880-1970. Pittsburgh, Pa.: University of Pittsburgh Press, 2009.

Uekötter, F. "Das Organisierte Versagen. Die deutsche Gewerbeaufsicht und die Luftverschmutzung vor dem ökologischen Zeitalter." Archiv für Sozialgeschichte 43 (2003): 127-150.

Verband der chemischen Industrie e.V., "Grosse Chemieunternehmen in Deutschland," in Die Welt 20 June 2011.

Verg, E., Plumpe, G. and Schultheis, M. Milestones: The Bayer Story 1863-1988. Leverkusen: the company, 1988.

Vollenweider, R.A. Water Management Research. Paris: OECD, 1968. 
von Randow, T. "Das Wasser ist krank. Wohin mit dem Abschaum der Zivilisation?" Die Zeit October 13, 1961: 36.

Wengenroth, Ulrich. "Germany: Competition abroad - Cooperation at Home, 1870-1990," in Big Business and the Wealth of Nations, ed. Chandler, A.D., Amatori, F. and T. Hikino. Cambridge: Cambridge University Press, 1997: 139-75.

Wiesen, J.S. West German Industry and the Challenge of the Nazi Past 1945-55. Chapel Hill: University of North Carolina Press, 2001.

Wilks, S., "The Embodiment of Industrial Culture in Bureaucracy and Management," in Capitalism in Contrasting Cultures, ed. Clegg, S. and S.G. Redding. Berlin, New York: W. de Gruyter, 1990: 131-52.

Wurzel, R. Environmental Policy-Making in Britain, Germany, and the European Union, Manchester: Manchester University Press, 2002.

\footnotetext{
${ }^{1}$ The authors would like to thank Henkel and Bayer for permission to use their archives, Oona Ceder for her valuable research assistance on the history of Henkel, and Thilo Jungkind.and Susanne Hilger for sharing her latest research on Henkel. They would like to thank Susanne Hilger, Chris Marquis, Andrew Spadafora, the participants of a session at the Business History Conference in Columbus, Ohio, March 21-23 2013, and several anonymous referees for many valuable comments on earlier drafts.

2 Rosen and Sellers, "The Nature of the Firm." Berghoff and Mutz, "Missing Links?" Rosen, "BusinessEnvironmental Connection;" Jones, "Entrepreneurship."

${ }^{3}$ Carroll, Corporate; Jones, "Debating".

${ }^{4}$ Guha, Environmentalism.

${ }^{5}$ Rosen, "Businessmen against Pollution."

${ }^{6}$ Brüggemeier, Meer der Lüfte.

${ }^{7}$ Dalton, Green Rainbow, 33.

${ }^{8}$ Souder, Farther Shore, part 2.

${ }^{9}$ Dalton, Green Rainbow, 38-9.

${ }^{10}$ Boullet, Entreprises.

${ }^{11}$ Hoffman, Heresy.

${ }^{12}$ Colten and Skinner, Road; Markowitz and Rosner, Deceit; Ross and Amter, Polluters.

${ }^{13}$ Kehoe, "Merchants"; McGucken, Lake Erie.

${ }^{14}$ Smith, "Turning".

15 Jones, Renewing, 339-347; Sluyterman, "Royal Dutch Shell;" Bergquist and Söderholm, "Green Innovation Systems."

16 Dalton, Green Rainbow; Wurzel, Environmental Policy-Making; Andersen and Liefferink, European Environmental Policy; Golub, New Instruments.

${ }^{17}$ Lampe and Gazda, "Green Marketing," 299.

${ }^{18}$ Brüggemeier, Meer der Lüfte; Büschenfeld, Flüsse oder Kloaken.

${ }^{19}$ Uekötter, Age; Hünemörder, Frühgeschichte. An exception for the time before 1930 is Mutz, Umwelt.

${ }^{20}$ Mikler, Greening. For an introduction to the general varieties of capitalism literature, see Hall and Soskice, Varieties.

${ }^{21}$ For the former view, see Bansal and Roth, "Why". For the alternative view, see Okhmatovskiy and David,

"Setting."

${ }^{22}$ Marquis and Toffel, "When."

${ }^{23}$ Lee and Green, "Towards Commercial."; Hopfenbeck, Green Management; Cairncross, Green, Inc.

${ }^{24}$ Feldenkirchen and Hilger, Menschen. Raasche, Wir Sind Bayer.

${ }^{25}$ Chandler, Shaping, 116, 134; Verband der chemischen Industrie e.V., Grosse Chemieunternehmen.

${ }^{26}$ Feldenkirchen and Hilger, Menschen, 228-33.

${ }^{27}$ Ibid, 16-36, 73-9. Schöne, Geschichte.

${ }^{28}$ Feldenkirchen and Hilger, Menschen, 62-4, 92-8, 110.

29 Jeffreys, Aspirin.

${ }^{30}$ Hayes, Industry and Ideology; Lindner, Inside IG Farben.

${ }^{31}$ Osterloh, Diese Angeklagten.

${ }^{32}$ Wiesen, West German Industry, 110.

${ }^{33}$ Ibid., 120-1. Cf. also Berghoff, "End"; Lubinski, "Path."

${ }^{34}$ Spector, "Business"; Carroll, Corporate.

${ }^{35}$ Hilger, "Reluctant", 194-8.

${ }^{36}$ Chandler, Shaping, 120-123, 135.

${ }^{37}$ Cassis, Big Business, 94, 99.
} 
${ }^{38}$ Cf. Abelshauser, Wirtschaftsgeschichte, 383-392.

${ }^{39}$ Uekötter, Age, 188-97.

${ }^{40}$ See Gutachten über Emissionsverhältnisse, Regional Council Düsseldorf 18 Sept. 1961, in: BAL 59/384 Ingenieurverwaltung, Abwasser- und Abluftlabor, hereafter: AWALU [Engineering Department, Effluents and Waste Air Laboratory], 1961-62. BAL 387/1 Vol. 3 Vorstandsprotokolle [Minutes of Board Meetings] 19581960, 2 Feb. 1960.

${ }^{41}$ HA 153/7 Postprotokolle [Minutes of Management Meeting], 20 Mar. 1951; Letter dated 28 Sept. 1966, HA Zug.-Nr. 451, Akten Opderbecke, Emissionen/Immissionen alt.

${ }^{42}$ Versicherungsabteilung [Insurance Department] 24 Jul. 1962, HA Zug.-Nr. 451, Akten Opderbecke, Emissionen/Immissionen alt.

43 "Bei Bayer stinkt's nach wie vor", Freies Volk, 09 Dec. 1955; "Der Leser hat das Wort", Rheinische Zeitschrift, 16 Feb. 1960, BAL 59/384 Ingenieurverwaltung [Engineering Department], AWALU, 1959-60.

${ }^{44}$ BAL 387/1 Vol. 8 Vorstandsprotokolle [Minutes of Board Meetings] 1966-1968, 18 Apr. 1966.

${ }^{45}$ HA 153/9 Postprotokolle [Minutes of Management Meeting], 09 Jun. 1953.

${ }^{46}$ BAL 59/384 Ingenieurverwaltung [Engineering Department], AWALU, 1961-62.

${ }^{47}$ Notiz des AWALU-Labors betreffend Auto-Lackschäden, 14 Dec. 1966, in: BAL 59/384 Ingenieurverwaltung [Engineering Department], AWALU, 1964-1967. All conversions to British pounds in this article are at contemporary exchange rates.

${ }^{48}$ Newspaper clippings in: BAL 59/384 Ingenieurverwaltung [Engineering Department], AWALU 1964-1967.

${ }^{49}$ Letter City of Düsseldorf to Henkel, 24 Sep. 1958, in: HA Zug.-Nr. 451, Akten Opderbecke, Abt. 501, 510 ab 1950; Direktions-Rundschreiben 1681, 1 Dec. 1955, in: BAL 59/384 Ingenieurverwaltung [Engineering Department], AWALU 1954-56.

50 Kommissionssitzung der Abwasser- und Abluftkommission, 2 Nov. 1959, in: BAL 59/384 Ingenieurverwaltung [Engineering Department], AWALU, 1959-60; Wengenroth, "Competition."

${ }^{51}$ Jones, Renewing, 342-3.

${ }^{52}$ von Randow, "Das Wasser ist krank."

${ }^{53}$ Staats, Entstehung, 60-75.

${ }_{55}^{54}$ Uekötter, Age, 168-175.

${ }^{55}$ Handelsblatt 14 August 1953. For the debate see also Hünemörder, Frühgeschichte, 78-80.

${ }^{56}$ Ibid.

${ }^{57}$ Ross and Amter, Polluters, 156.

${ }^{58}$ Bundesministerium der Justiz, "Gesetz Über Detergentien."

${ }^{59}$ Vorwärts, May 3, 1961.

${ }^{60}$ Quoted in: Uekötter, Age, 247.

61 "Blauer Himmel Über Der Ruhr," title and 22-33.

${ }^{62}$ BAL 387/1 Vol. 6 Vorstandsprotokolle [Minutes of Board Meetings] 1963-1965, 17 Jul. 1963; HA E 20 Juristische Abteilung [Juridical Department], Referat Dr. Erben, 4 Apr. 1967.

${ }^{63}$ Hünemörder, Frühgeschichte, 159-171, 209-214.

${ }^{64}$ HA J 105 Betriebskonferenzen 1943-76, 3 Feb. 1959.

${ }^{65}$ HA 603 Umweltschutz 1990-2, Dr. Peter Berth, "Grundsätzliche Anmerkungen zur Ökologie der Tenside," internal company research report, undated [c. 1989]: 10, 24; Gassdorf and Henkel KGaA, It All Started with Water Glass, 8-13, 24.

${ }^{66}$ Kohoe, "Merchants", 26-27; Jones, Renewing, 342; Dyer, Rising, 108.

${ }^{67}$ BAL 59/384 Ingenieurverwaltung [Engineering Department], AWALU, 1954-1956, Direktionsrundschreiben 23 Jul. 1954.

${ }^{68}$ BAL 59/384 Ingenieurverwaltung [Engineering Department], AWALU, 1967-1971, Luftüberwachung Nov. 1967.

${ }^{69}$ Henkel "Company History." URL: http://www.henkel.com/about-henkel/company-history-11789.htm (accessed: 24 May, 2013.)

${ }^{70}$ BAL 59/384 Ingenieurverwaltung [Engineering Department], AWALU 1954-56, Letter by Engineering Department to AWALU, 2 Feb. 1956.

${ }^{71}$ Jungkind, Störfall- und Umweltrisiko, 185.

72 BAL 59/384 Ingenieurverwaltung [Engineering Department], AWALU, 1961-62, letter AWALU to Prof. Rieß, 12 Jul. 1960; ibid., 1959-60, letter Dr. Wolff to chief engineer, 17 Nov. 1960.

${ }^{73}$ HA J 105, Betriebskonferenzen 1943-76, 10 Oct. 1960.

74 BAL 59/384 Ingenieurverwaltung [Engineering Department], AWALU 1954-1956, Henkel to Rieß re AWALU-commission, 1 Jul. 1955.

${ }^{75}$ HA J 106, Meisterkonferenz 1949-1967, 21 Jul. 1959; HA E 20 Juristische Abteilung [Juridical Department], Referat Dr. Erben, 4. Apr. 1967. 
${ }^{76}$ BAL 59/384 Ingenieurverwaltung [Engineering Department], AWALU, 1954-56, letter Rieß to Ritter, 10 Aug. 1955.

${ }^{77}$ Uekötter, Age, 175.

${ }^{78}$ BAL 59/384 Ingenieurverwaltung [Engineering Department], AWALU 1964.

${ }^{79}$ German Chemical Industry Association (Verband der chemischen Industrie) Wirtschaftliche Mitteilungen der Niederrheinischen IHK Duisburg-Wesel Nr. 4/67, 11 May 1967, in: HA, unverzeichnete Akte Verband der chemischen Industrie.

${ }^{80}$ BAL Bayer Annual Report 1969, 17.

${ }^{81}$ HA J 105, Betriebskonferenzen 1943-1976, 7 March 1967. For the state as active partner in coordinated market economies see Hall and Soskice, "Introduction", 57.

${ }^{82}$ BAL 59/384 Ingenieurverwaltung [Engineering Department], AWALU, 1964-67, Vermerk von Dir. Dr. Heimsothe, 11 Nov. 1966 in Düsseldorf.

${ }^{83}$ HA Zug.-Nr. 314, Akten Opderbecke, Abt. 651 Ingenieurwesen/Jahres- und Quartalsberichte 1958-65, Jahresbericht 21 Nov. 1960, 6; BAL 59/384 Ingenieurverwaltung, AWALU, 1960-61, letter Rieß to Haberland, 21 Oct. 1960.

${ }^{84}$ Hall and Soskice, "Introduction", 26-7.

${ }^{85}$ See especially Colten and Skinner, Road; Markowitz and Rosner, Deceit; Kehoe, "Merchants."

${ }^{86}$ Uekötter, Age, 175-6, 264-5.

${ }^{87}$ Smith. "Turning."

${ }^{88}$ Uekötter, Age, 184.

${ }^{89}$ Mann, Lösung, 39-40.

${ }^{90}$ Quoted in Uekötter, Age, 185.

91 Beeton, Eutrophication; Vollenweider, Water Management Research; Kehoe,"Merchants“, 25-30; Jones, Renewing, 342-5.

92 "Konrad Henkel Ist Tot."

93 HA 603 Umweltschutz 1990-2, "Umweltmonitoring bei Henkel" URL: http://www.henkel.com/abouthenkel/company-history-11789.htm (accessed: 24 May, 2013); ibid., "Änderungen wichtiger Wasserqualitätsparameter im Rhein bei Düsseldorf," undated [c. 1989].

${ }^{94}$ Jones, Renewing, 343; Kohoe, „Merchants,“ 30-33.

${ }^{95}$ Carroll, Corporate, 242-245.

96 "Gesellschaft Und Umwelt."

${ }^{97}$ BAL 59/384 Ingenieurverwaltung [Engineering Department], AWALU, 1967-1971, Landtag NRW-Sechste Wahlperiode, Kleine Anfrage 25 Nov. 1968.

${ }^{98}$ Ibid., letter Ministry of Labour and Social Affairs NRW, 20 Dez. 1968.

${ }^{99}$ Ibid., letter Ministry of Labour and Social Affairs NRW to Vorstand Bayer AG, 30 Dec. 1968.

${ }^{100}$ BAL 59/385 Ingenieurverwaltung, AWALU, 1967-71, letter Heidecke to Bayer AG, 23 Sep. 1969.

${ }^{101}$ HA 153/49, Post ZGF Nr. 33, "Umweltprobleme-Initiative des Bundesministeriums, 25 Aug. 1970, 6.

${ }^{102}$ Kohoe, "Merchants" 32; Dyer, Rising, 108-9.

${ }^{103}$ Haus der Geschichte "Regierungserklärung Willy Brandt." URL: http://www.hdg.de/lemo/html/dokumente/KontinuitaetUndWandel_erklaerungBrandtRegierungserklaerung1969/ index.html (accessed: 24 May, 2013.)

${ }^{104}$ Wurzel, Environmental Policy-Making, 19-20, 24.

${ }^{105}$ Uekötter, Age, 253.

106 Kloepfer et al., Geschichte. Umweltbundesamt. URL: http://www.umweltbundesamt.de/index-e.htm (accessed: 24 May, 2013.)

107 HA Zug.-Nr. 451 Akten Opderbecke Umweltschutz bis 1978, survey by the Institut für Angewandte Sozialwissenschaften.

${ }^{108}$ BA 388/130 Notiz fuer K. Hansen und G. Broja, 30 Jun. 1972.

${ }^{109}$ Gruhl, Ein Planet; Bramwell, Ecology, 219-221. Gruhl left the CDU in 1978.

${ }^{110}$ HA Stabstelle Öffentlichkeitsarbeit, Firmenbildstudien 1969-1983, speech Konrad Henkel, 29 Apr. 1971.

${ }^{111}$ HA 153/45 Gemeinsame Post [Management Meeting], 16 Mar. 1971.

${ }^{112}$ Dyer, Rising, 109.

${ }^{113}$ Hoffman, Heresy, chapter 4.

${ }^{114}$ Markowitz and Rosner, Deceit, 210-211.

115 Greer and Bruno, Greenwash.

${ }^{116}$ Hilger, Reluctant, 204-5.

117 HA 455155, ST-PR, Bohmert, Das PR-Konzept des Unternehmens Henkel, 13.6.1969. Cf. Hilger, Amerikanisierung, 262-5.

${ }^{118}$ Henkel-Blick 6/1974: 2.

${ }^{119}$ HA 153/49 Post ZGF Nr. 33, [Minutes of Management Meeting], 25 Aug. 1970, 6. 
${ }^{120}$ HA 153/45 Gemeinsame Post [Minutes of Management Meeting], 16 Mar. 1971, 4-5; Peter Berth, "Aktuelle Probleme des Umweltschutzes," 20. Technische Waschmittelkonferenz, 25-6 September 1972, 2.

${ }^{121}$ HA 603 Umweltschutz 1971, PR-Aktion "Gespräch mit dem Nachbarn," 9 Dec. 1971, 1.

${ }^{122}$ Ibid., statement to the press by Dr. Friedrich Bohmert, Public Relations, Dec. 1975, 4-5; for the internal debate cf. Referat Bohmert, 28 Nov 1971, 3-4.

${ }^{123}$ Ibid., statement to the press by Dr. Friedrich Bohmert, Public Relations, Dec. 1975, 4-6.

${ }^{124}$ Ibid, 6-7.

${ }^{125}$ Dr. Grunewald, "Grenzen des Wachstums," presentation at the 20. Technische Waschmittelkonferenz, 25-26 Sep. 1972, 92.

${ }^{126}$ HA 603 Umweltschutz 1989, "Ökologisch orientiertes Management bei Henkel," undated (c. 1989.)

${ }^{127}$ HA 153/6 Gemeinsame Postbesprechung [Management Meeting] Nr. 12/1972, 5. Dec. 1972.

${ }^{128}$ Dr. Heise, Industrie und Gesellschaft, presentation at the 21. Technische Waschmittelkonferenz, 30-31 Aug. $1973,2$.

${ }^{129}$ HA 603 Umweltschutz 1990-2, Berth, "Grundsätzliche Anmerkungen zur Ökologie der Tenside," internal company research report, undated [c. 1989], 3.

${ }^{130}$ HA C7300, Sasil, press release 25 Nov. 1976, 2.

${ }^{131}$ Helmut Siehler at the panel discussion "Marketing and Wohlfahrtsökonomie" published as Freter, Marketing, 500 .

${ }^{132}$ Kleinschmidt, Blick, 104, 240, 360.

${ }^{133}$ Koch and Vahrenholt, Seveso ist Überall.

${ }^{134}$ Dyer et al., Rising, 109.

135 HA 603 Umweltschutz 1971,Verbraucherbewegung-Verbraucherschutz-Umweltschutz: Firmenpolitische Stellungnahme und Sachinformationen, Public Relations, 28 Jun. 1973, 8-9.

${ }^{136}$ Dyer et al., Rising, 109. Knud-Hansen, Historical Perspective.

${ }^{137}$ HA 603 Umweltschutz 1989, "DIXAN" press release, undated (c. January, 1983); H603 Umweltschutz 1990-

2, public relations, letter Lengsdorf to the Saarbrücker Zeitung, 3 Aug. 1990; http://www.henkel.com/abouthenkel/company-history-11789.htm\#top (accessed: 24 May, 2013.)

${ }^{138}$ HA 603 Umweltschutz 1990-2, public relations, letter Lengsdorf to the Saarbrücker Zeitung, 3 Aug. 1990.

${ }^{139}$ Ibid., letter to Braungart, Hamburger Umweltinstitut, 11 Oct., 1990.

${ }^{140}$ Henkel. http://www.henkel.com/about-henkel/company-history-11789.htm\#top (accessed 24 May, 2013.)

${ }^{141}$ Jones, Renewing, 355.

${ }_{142}$ BAL 388/129 Awalu and Presse-Information Umweltschutz 3 August 1971; BAL 388/135 letter Henkel to Meinck, 25 April 1974.

${ }^{143}$ BAL 388/140 Werksverwaltung Leverkusen AWALU Allgemein ab 1 Jul. 1974, Memorandum der AWALU Kommission, 23 Sept. 1974, 4.

144 "Konjunktur geht vor", Der Spiegel 26 May 1975.

145 "Fisch vor die Tür", Der Spiegel 31 August 1981.

146 "SPIEGEL-Interview mit Bayer-Vorstandschef Herbert Grünewald,” Der Spiegel 9 December 1977.

${ }^{147}$ Dauvergne and Lister, Eco-Business.

${ }^{148}$ BAL 388137 Awalu an Weber 22 Apr. 1975; BAL Bayer AG Annual Reports.

149 BAL 59/384 Ingenieurverwaltung [Engineering Department], AWALU, several reports. There were significant exchange rate movements during the 1970s. In $1974 £ 1$ was $6.04 \mathrm{DM}$; in 1979 it was 3.88 DM.

${ }^{150}$ Verg, Plumpe and Schultheiss, Milestones, 427.

${ }^{151}$ BAL Bayer AG Annual Reports 1970 to 1975.

${ }^{152}$ Mann "Lösung."

${ }^{153}$ Verg, Plumpe and Schultheiss, Milestones, 524, 528.

${ }^{154}$ BAL Ingenieurverwaltung [Engineering Department] AWALU 1973-1988, LE Umweltschutz/AWALU 8 May 1981.

${ }_{155}^{155}$ Bayer AG. URL: http://www.bayer.de/de/umwelt-und-natur.aspx (accessed: 24 May, 2013.)

${ }^{156}$ Moeller and Winkler "The Double Contact Process."

${ }^{157}$ BAL Bayer AG Annual Report 1980, 36.

${ }^{158}$ BAL 388/131 Vortrag Henkel in Wien, 11 Jan. 1972.

${ }^{159}$ BAL 388/91 Bayer-Imagewerbung 1973/Fernsehwerbung, Febr. 1973.

${ }^{160}$ BAL 388/214 Werksverwaltung Leverkusen AWALU II, Weber to Broja, 4 Jan. 1972.

${ }^{161}$ BA 388/131 Aktennotiz Besprechung am 14 Nov. 1972 Leverkusen Werksverwaltung, Abt. AWALU.

${ }^{162}$ BAL 388/212 Letter Jacobi to Broja, 29 Jun. 1973; ibid. Bayer Presseinformation, Leverkusener Forum, 19 Jun. 1974. Over 7,400 people, among them 2,100 school children, visited the exposition in 4 days.

${ }^{163}$ BAL 388/165 Notiz for Weber, 6 Nov. 1974.

${ }^{164}$ BAL 388/131 AWALU II, Henkel and Broja, 25 Apr. 1972. 
165 Ibid. Beratung von Kunden in Umweltfragen 1972; BAL 388/132 Katalog von Bayer Maßnahmen mit positiver ökologischer Relevanz, 30 Jan. 1973.

${ }^{166}$ BAL 388/29 Vermerk Bayer Zentralbereich Werbung und Marktforschung, 14 Oct. 1976.

${ }^{167}$ Hoffmann, "Der Grüne Riese."

${ }^{168}$ BAL 388/214 Protokoll der Ausschuss-Sitzung "Umweltschutz-Information", 13 Feb. 1980.

${ }^{169}$ Dauvergne and Lister, Eco-Business, 2. 